\title{
A Dynamic System of Growth and Yield Equations for Pinus patula
}

\author{
Wenceslao Santiago-García 1,* (D) Eloísa Pérez-López ${ }^{1}$, Gerónimo Quiñonez-Barraza ${ }^{2}$ [D , \\ Gerardo Rodríguez-Ortiz $^{3}$ (D), Elías Santiago-García ${ }^{4}$, Faustino Ruiz-Aquino ${ }^{1}$ \\ and Juan Carlos Tamarit-Urias 5 \\ 1 Instituto de Estudios Ambientales-División de Estudios de Postgrado-Ingeniería Forestal, \\ Universidad de la Sierra Juárez, Avenida Universidad s/n, 68725 Ixtlán de Juárez, Oaxaca, Mexico; \\ elois_aple@hotmail.com (E.P.-L); ruiz.aquino@unsij.edu.mx (F.R.-A.) \\ 2 Centro de Investigación Regional Norte Centro, Campo Experimental Valle del Guadiana, \\ Instituto Nacional de Investigaciones Forestales, Agrícolas y Pecuarias, \\ Carretera Durango-Mezquital Km 4.5, 34170 Durango, Durango, Mexico; gero2723@hotmail.com \\ 3 División de Estudios de Posgrado e Investigación-Instituto Tecnológico del Valle de Oaxaca, \\ Ex Hacienda de Nazareno s/n, 71230 Xoxocotlán, Oaxaca, Mexico; geraro65@gmail.com \\ 4 Dirección Técnica Forestal de la Comunidad de Ixtlán de Juárez, Oaxaca, Carretera Oaxaca-Tuxtepec s/n, \\ 68725 Ixtlán de Juárez, Oaxaca, Mexico; forestal_esg@live.com \\ 5 Centro de Investigación Regional Golfo Centro, Campo Experimental San Martinito, Instituto Nacional de \\ Investigaciones Forestales, Agrícolas y Pecuarias, Carretera Federal Mexico-Puebla Km 56.5, \\ 74100 Santa Rita Tlahuapan, Puebla, Mexico; tamarit.juan@inifap.gob.mx \\ * Correspondence: wsantiago@unsij.edu.mx; Tel.: +52-951-220-3466
}

Received: 1 October 2017; Accepted: 23 November 2017; Published: 28 November 2017

\begin{abstract}
Sustainable forest management needs tools that can predict how silvicultural treatments will affect cutting stands. Growth and yield systems are an example of these tools because they can represent periods of growth and yield of a stand in numerical terms. The aim of this research was to develop a dynamic growth and yield timber system with the stand-level models approach for Pinus patula in even-aged forests of Ixtlán de Juárez, Oaxaca, Mexico. The data was obtained from two consecutive remeasurements of 66 permanent $400 \mathrm{~m}^{2}$ plots. With this information, prediction and projection equations in the algebraic difference approach for mean diameter at breast height $(D B H)$, basal area and total volume per hectare were fitted through the seemingly unrelated regression technique. Mortality was fitted by the non-linear least squares method. A model of dominant height and site index (Levakovic II) with polymorphism was related to basal area, DBH, total volume ha ${ }^{-1}$ and mortality equations. The growth system generated an average optimal age rotation of 32 years when the current annual increment (CAI) was the same as the mean annual increment (MAI) for the mean site index and a density of 1500 trees ha $^{-1}$ at five years. The growth and yield system developed is an important tool for planning forest management of even-aged P. patula forests.
\end{abstract}

Keywords: forest management; forest monitoring; modeling resource assessment; stand level models

\section{Introduction}

Pinus patula Schiede ex Schlechtendal \& Chamisso, an endemic species of Mexico, is distributed in Mexico City and the states of Chiapas, Mexico, Hidalgo, Morelos, Oaxaca, Puebla, Querétaro, Tamaulipas, Tlaxcala and Veracruz [1]. The species is important for timber and commercial interest around the world due to its relatively rapid growth rate and adaptation. P. patula is, in fact, largely used for plantations in tropical and subtropical regions of the world, such as South America, Central and Southern Africa and Indonesia even in Australia and New Zealand [1,2]. It is therefore necessary 
to incorporate biometric tools to determine the growth of this species to develop suitable forest management programs and to identify and consider various factors simultaneously in space and time. In this way, decision-making in planning forest management activities is facilitated, for example, levels of timber production and other goods, as well as those silvicultural treatments that allow the maintenance of desirable conditions in stands and in the forest in general [3].

The systems of growth and timber yield (SGTY) are part of the biometric instruments that can project and simulate changes in forest stands over time. A growth system refers to a set of mathematical equations that dynamically predict the growth and yield of a stand under a variety of present and future management conditions [4]. This dynamics is reflected in the changes in magnitude of stand variables such as dominant height $(D H)$, average tree diameter, basal area, number of trees ha ${ }^{-1}$ and volume [5].

Of the variables used in the construction of SGTYs, DH is one of the variables least affected by changes in density and by intermediate silvicultural treatments. In addition, it is closely related to total volume, making it a simple indicator of productivity that is easy to evaluate [6]. This variable can be predicted with dynamic equations, which project $D H$ to a future state from the current age and height. This type of equation can be obtained using the algebraic difference approach (ADA) [7] with which families of anamorphic or polymorphic curves are obtained, or through the generalized algebraic difference approach (GADA) [8], which results in families of polymorphic curves with multiple asymptotes.

Timber volume is the variable of greater interest due to its economic importance at the stand level. It can be estimated from the age, dominant height, basal area and number of trees. These interrelated variables, when expressed with dynamic models of growth, permit simulations of silvicultural management scenarios and the evaluation of the effect in terms of growth and increment [9].

In Mexico, SGTYs have been developed, mainly for natural even-aged stands and plantations [5,10-16]. However, for most Mexican forests, there is still no research on growth rates and timber yield over time to plan and evaluate sustainable forest management.

The objective of the present research was to develop systems of growth and timber yield under the explicit modeling approach for even-aged P. patula stands located in forests of Ixtlán de Juárez, Oaxaca, Mexico, and with this, to be able to advance the knowledge of the decision-making processes of sustainable forest management.

\section{Materials and Methods}

\subsection{Study Area}

The study was developed in P. patula stands of Ixtlán de Juárez, Oaxaca, Mexico (Figure 1). The study area is located between the coordinates $17^{\circ} 23^{\prime} 0.50^{\prime \prime}-17^{\circ} 23^{\prime} 0.58^{\prime \prime} \mathrm{N}$ and $96^{\circ} 28^{\prime} 45^{\prime \prime}-$ $96^{\circ} 28^{\prime} 53^{\prime \prime} \mathrm{W}$, with an average altitude of $2780 \mathrm{~m}$. The region is located in the physiographic province called "Mountain System of the North of Oaxaca". The predominant types of climate in the area are temperate sub-humid and temperate sub-humid with summer rains, with an average annual temperature of $14^{\circ} \mathrm{C}$ to $18{ }^{\circ} \mathrm{C}$. The most common soil groups in the area are Acrisols, Luvisols and Cambisols. The dominant vegetation is pine-oak forest [17]. In the forests of the study area, P. patula is managed through strip clear-cutting with immediate planting after harvest. Planting density ranges from 2300 to 2600 trees per hectare, and is complemented by natural regeneration. 


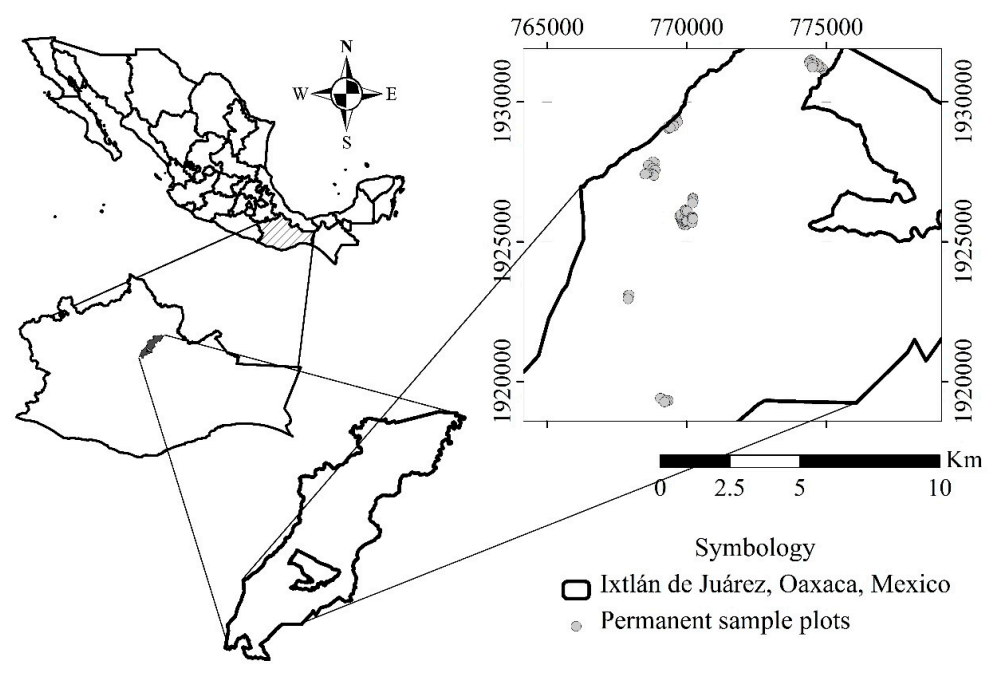

Figure 1. Location of the study area.

\subsection{Forest Inventory Data}

The database used in this study was obtained from two inventories at 66 permanent $400 \mathrm{~m}^{2}$ sampling plots during the years 2015 and 2016. The plots cover a wide range of ages, site qualities and density levels, which allowed modeling growth conditions of different stands. However, there is a lack of information in the age range of 25 to 50 years old, but since there are data from five-year-old stands and from stands older than 70 years, it was possible to have a consistent database to give plasticity to growth and yield models. The collected data were diameter at breast height $(D B H)$ of all trees within the site, height of at least eight trees per site, of which four were identified as dominant according to the definition of dominant height corresponding to the 100 tallest trees or greater $D B H$ per hectare $[18,19]$, as well as the number of live trees.

To estimate the height of the unmeasured trees, we used the generalized allometric model proposed by Jacinto-Salinas [20]:

$$
T H=1.3+(42.25444+0.999659 \times D H+0.16147 \times Q D) \exp \left(\frac{-6.483097}{\sqrt{D B H}}\right)
$$

$\left(\right.$ Root of mean square error $(R M S E)=4.307, R^{2}$ adj $\left.=0.75\right)$

where $T H=$ total height of the tree $(\mathrm{m}) ; D H=$ average dominant height of the site $(\mathrm{m}) ; Q D=$ quadratic mean diameter $(\mathrm{cm}) ; D B H=$ diameter at breast height with bark $(\mathrm{cm})$, and; exp = exponential function.

The volume of individual trees was estimated from the Schumacher-Hall equation fitted by Rodríguez-Justino [21]:

$$
\begin{gathered}
v=0.000063 \times D B H^{1.632488} \times T H^{1.237181} \\
\left(R M S E=0.139, R^{2} a d j=0.98\right)
\end{gathered}
$$

where $v$ is the bole volume of the individual tree $\left(\mathrm{m}^{3}\right)$ with bark excluding the stump, and the other variables were previously defined. From the individual tree forest measurement data, the following variables were estimated: average height of dominant trees $(D H, \mathrm{~m})$; arithmetic mean diameter at breast height $(D B H, \mathrm{~cm})$; basal area $\left(B A, \mathrm{~m}^{2} \mathrm{ha}^{-1}\right)$; total volume $\left(V, \mathrm{~m}^{3} \mathrm{ha}^{-1}\right)$, and; the number of live trees $\left(L T \mathrm{ha}^{-1}\right)$. Descriptive statistics for the fit of growth models were obtained (Table 1 ) and the trajectories of the data pattern with age (Figure 2). 
Table 1. Statistical summary of 66 permanent sampling plots used in the fit of the dynamic equations.

\begin{tabular}{ccccc}
\hline Variable & Mean & Standard Deviation & Minimum & Maximum \\
\hline$A_{1}$ & 18.22 & 16.93 & 5.00 & 74.25 \\
$A_{2}$ & 19.22 & 16.93 & 6.00 & 75.25 \\
$D H_{1}$ & 14.78 & 6.35 & 4.55 & 34.85 \\
$D H_{2}$ & 16.00 & 6.17 & 6.32 & 35.41 \\
$D B H_{1}$ & 13.37 & 6.63 & 5.75 & 39.21 \\
$D B H_{2}$ & 14.44 & 6.36 & 7.14 & 39.84 \\
$B A_{1}$ & 21.22 & 14.06 & 1.35 & 66.53 \\
$B A_{2}$ & 23.82 & 13.46 & 2.59 & 68.26 \\
$V_{1}$ & 160.76 & 159.59 & 3.62 & 618.24 \\
$V_{2}$ & 191.56 & 169.73 & 9.01 & 665.33 \\
$L T_{1}$ & 1525.38 & 1024.50 & 300.00 & 6050.00 \\
$L T_{2}$ & 1510.61 & 1006.83 & 300.00 & 6025.00 \\
\hline
\end{tabular}

Where $A_{1}=$ initial stand age (years), $A_{2}=$ final stand age (years), $D H_{1}=$ dominant height (m) at $A_{1}, D H_{2}=$ dominant height (m) at $A_{2}, D B H_{1}=$ average stand of diameter at breast height $(\mathrm{cm})$ at $A_{1}, D B H_{2}=$ average stand of diameter at breast height $(\mathrm{cm})$ at $A_{2}, B A_{1}=$ basal area $\left(\mathrm{m}^{2} \mathrm{ha}^{-1}\right)$ at $A_{1}, B A_{2}=$ basal area $\left(\mathrm{m}^{2} \mathrm{ha}^{-1}\right)$ at $A_{2}, V_{1}=$ volume $\left(\mathrm{m}^{3} \mathrm{ha}^{-1}\right)$ at $A_{1}, V_{2}=$ volume $\left(\mathrm{m}^{3} \mathrm{ha}^{-1}\right)$ at $A_{2}, L T_{1}=$ number of live trees ha ${ }^{-1}$ at $A_{1}, L T_{2}=$ number of live trees ha ${ }^{-1}$ at $A_{2}$. The subscripts 1 and 2 correspond to measurements made during the years 2015 and 2016, respectively.

\subsection{Development of Compatible Models}

The compatible SGTYs are made up of two types of functions: prediction equations and their respective projection functions for the state variables $D H, B A, D B H$ and $V$; a prediction model allows the characterization of the average condition of the stand at a given age, while a projection model predicts the future values of stand status variables from an initial state [5]. The first step in the construction of the SGTY was to determine the station quality of the forest or stand, which requires equations to calculate the $D H$ and site index (SI, which refers to the dominant height of the stand at a reference age $(R A)$ ) [6]. In this study we considered the expression polymorphic of Levakovic II fitted by Pérez-López [22], considering 40 years as base age and its corresponding equation to estimate the dominant height:

$$
\begin{gathered}
S I=52.76080\left[\frac{40}{A\left[-1+(D H / 52.76080)^{-0.32193}\right]+40}\right]^{3.10631} \\
D H=52.76080\left[\frac{A}{40\left[-1+(S I / 52.76080)^{-0.32193}\right]+A}\right]^{3.10631} \\
\left(\text { RMSE }=0.339, R^{2} \text { adj }=0.99\right) .
\end{gathered}
$$

The compatible growth equations in mean diameter at breast height, basal area and total volume per hectare were obtained with the algebraic difference approach. In general, an equation in algebraic differences has the form $y_{2}=f\left(y_{1}, A_{1}, A_{2}, \beta\right)$, where $y_{2}$ is the value of the variable analyzed at an age $A_{2}$ (projection age), $y_{1}$ is the variable analyzed at age $A_{1}$ (initial age), and $\beta$ is the vector of regression parameters $[6,14,23]$.

For the modeling of the arithmetic mean diameter and basal area, the models of Piennar et al. [24] and Hui and Gadow [25] were fitted, the corresponding prediction and projection equations were:

Piennar et al. [24] model:

$$
\begin{gathered}
D B H_{1}=\exp \left(\beta_{0}+\beta_{1} A_{1}^{-1}+\beta_{2} \ln \left(L T_{1}\right)+\beta_{3} \ln \left(D H_{1}\right)\right) \\
D B H_{2}=\exp \left[\ln \left(D B H_{1}\right)+\beta_{1}\left(A_{2}^{-1}-A_{1}^{-1}\right)+\beta_{2} \ln \left(\frac{L T_{2}}{L T_{1}}\right)+\beta_{3} \ln \left(\frac{D H_{2}}{D H_{1}}\right)\right]
\end{gathered}
$$


Hui and Gadow [25] model:

$$
\begin{gathered}
D B H_{1}=\exp \left(\beta_{0}+\left(1-\beta_{1} D H_{1} \beta_{2}\right) \ln \left(L T_{1}\right)+\beta_{3} \ln \left(D H_{1}\right)\right) \\
D B H_{2}=\exp \left[\ln \left(D B H_{1}\right)+\left(1-\beta_{1} D H_{2}{ }^{\beta_{2}}\right) \ln \left(L T_{2}\right)+\left(\beta_{1} D H_{1}^{\beta_{2}}-1\right) \ln \left(L T_{1}\right)+\beta_{3} \ln \left(\frac{D H_{2}}{D H_{1}}\right)\right]
\end{gathered}
$$

Piennar et al. [24] model:

$$
\begin{gathered}
B A_{1}=\exp \left(\beta_{0}+\beta_{1} A_{1}^{-1}+\beta_{2} \ln \left(L T_{1}\right)+\beta_{3} \ln \left(D H_{1}\right)\right) \\
B A_{2}=\exp \left[\ln \left(B A_{1}\right)+\beta_{1}\left(A_{2}^{-1}-A_{1}^{-1}\right)+\beta_{2} \ln \left(\frac{L T_{2}}{L T_{1}}\right)+\beta_{3} \ln \left(\frac{D H_{2}}{D H_{1}}\right)\right]
\end{gathered}
$$

Hui and Gadow [25] model:

$$
\begin{gathered}
B A_{1}=\exp \left(\beta_{0}+\left(1-\beta_{1} D H_{1} \beta_{2}\right) \ln \left(L T_{1}\right)+\beta_{3} \ln \left(D H_{1}\right)\right) \\
B A_{2}=\exp \left[\ln \left(B A_{1}\right)+\left(1-\beta_{1} D H_{2}{ }^{\beta_{2}}\right) \ln \left(L T_{2}\right)+\left(\beta_{1} D H_{1} \beta_{2}-1\right) \ln \left(L T_{1}\right)+\beta_{3} \ln \left(\frac{D H_{2}}{D H_{1}}\right)\right]
\end{gathered}
$$

where $D B H_{1}=$ arithmetic mean diameter $(\mathrm{cm})$ at the initial age $\left(A_{1}\right.$, in years), $D B H_{2}=$ arithmetic mean diameter $(\mathrm{cm})$ at the projection age $\left(A_{2}\right.$, in years), $L T_{1}=$ number of live trees per hectare at the initial age, $L T_{2}=$ number of live trees per hectare at the projection age, $D H_{1}=$ dominant height $(\mathrm{m})$ at the initial age, $D H_{2}=$ dominant height $(\mathrm{m})$ at the projection age, $B A_{1}=$ basal area $\left(\mathrm{m}^{2} \cdot \mathrm{ha}^{-1}\right)$ at the initial age, and $B A_{2}=$ basal area $\left(\mathrm{m}^{2} \mathrm{ha}^{-1}\right)$ at the projection age.

As for volume, the following equations were tested:

Santiago-García et al. [16] model:

$$
\begin{gathered}
V_{1}=\exp \left(\delta_{0}+\delta_{1} \frac{D H_{1}}{B A_{1}}\right) A_{1} \delta_{2} D H_{1} \\
V_{2}=\exp \left[\ln \left(V_{1}\right)+\delta_{1}\left(\frac{D H_{2}}{B A_{2}}-\frac{D H_{1}}{B A_{1}}\right)\right]\left(\frac{A_{2}}{A_{1}}\right)^{\delta_{2}}\left(\frac{D H_{2}}{D H_{1}}\right)
\end{gathered}
$$

Santiago-García [26] model:

$$
\begin{gathered}
V_{1}=\exp \left(\delta_{0} \ln (S I)+\delta_{1} A_{1}{ }^{-1}+\delta_{2} \ln \left(B A_{1}\right)\right) \\
V_{2}=V_{1} \exp \left[\left(\delta_{1}\left(A_{2}{ }^{-1}-A_{1}^{-1}\right)+\delta_{2} \ln \left(\frac{B A_{2}}{B A_{1}}\right)\right)\right]
\end{gathered}
$$

where $V_{1}=$ volume $\left(\mathrm{m}^{3} \mathrm{ha}^{-1}\right)$ at the initial age $\left(A_{1}\right.$, in years), $V_{2}=$ volume $\left(\mathrm{m}^{3} \mathrm{ha}^{-1}\right)$ at the projection age $\left(A_{2}\right.$, in years), $D H_{1}=$ dominant height $(\mathrm{m})$ at the initial age, $D H_{2}=$ dominant height $(\mathrm{m})$ at the projection age, $B A_{1}=$ basal area $\left(\mathrm{m}^{2} \mathrm{ha}^{-1}\right)$ at the initial age, $B A_{2}=$ basal area $\left(\mathrm{m}^{2} \mathrm{ha}^{-1}\right)$ at the projection age, and $S I=$ site index $(\mathrm{m})$.

As a complementary part of the estimation of the timber yield, at the hectare level it was necessary to forecast the number of surviving trees at a given time, for which the following mortality equations were tested $[9,27]$ :

$$
\begin{gathered}
L T_{2}=L T_{1} \exp \left[\alpha_{1}\left(A_{2}-A_{1}\right)\right] \\
L T_{2}=L T_{1} \exp \left[\alpha_{1} S I\left(A_{2}-A_{1}\right)\right]
\end{gathered}
$$

where $L T_{1}=$ number of live trees per hectare at the initial age $\left(A_{1}\right.$, in years), and $L T_{2}=$ number of live trees per hectare at the projection age $\left(A_{2}\right.$, in years). 


\subsection{Fitting Models and Statistical Analysis}

The components of the SGTY were adjusted simultaneously using the seemingly unrelated regression technique (SUR) with the MODEL procedure of SAS/ETS ${ }^{\circledR} 9.3$ [28], except for the mortality function that was adjusted using the non-linear least squares method. The SUR technique provides a more efficient parameter estimation when the components of the error are correlated in a system of equations. It also allowed compatibility between the prediction and projection models, so that both equations take the same values of the parameter estimators and the criterion of minimizing the sum of squares of the residues $[29,30]$.

The goodness of fit of the studied models was measured through numerical and graphic analysis of residuals, according to statistics of variability and precision (Table 2). In addition, the predictions and projections of the models were analyzed graphically to verify the logical behavior with respect to the data used.

Table 2. Statistical indicators used to evaluate the goodness of fit of the growth and yield equations.

\begin{tabular}{|c|c|}
\hline Indicator & Equations \\
\hline Sum of squares of error (SSE) & $S S E=\sum_{i=1}^{n}\left(y_{i}-\hat{y}_{i}\right)^{2}$ \\
\hline Root of mean square error (RMSE) & $R M S E=\sqrt{\frac{\sum_{i=1}^{n}\left(y_{i}-\hat{y}_{i}\right)^{2}}{n-p}}$ \\
\hline $\begin{array}{l}\text { Coefficient of determination adjusted by the } \\
\text { number of parameters }\left(R^{2} a d j\right)\end{array}$ & $R_{a d j}^{2}=1-\left(\frac{n-1}{n-p} \times \frac{\sum_{i=1}^{n}\left(y_{i}-\hat{y}_{i}\right)^{2}}{\sum_{i=1}^{n}\left(y_{i}-\bar{y}\right)^{2}}\right)$ \\
\hline Absolute average bias $(\bar{E})$ & $\bar{E}=\mid \frac{\sum_{i=1}^{n}\left(y_{i}-\hat{y}_{i}\right)}{n}$ \\
\hline Akaike information criterion $(A I C)$ & $A I C=2 p+n \ln \mid \frac{\sum_{i=1}^{2}\left(y_{i}-y_{i}\right)}{n}$ \\
\hline
\end{tabular}

Where $\overline{y_{i}}, \bar{y}$ and $\hat{y}_{i}$ are the observed value, the mean of the observation and predicted of the dependent variable, respectively; $n=$ number of observations, $p=$ number of model parameters to be evaluated.

\section{Results}

\subsection{Growth Models}

The adjustment of the equations to model growth in mean diameter, basal area, volume and mortality was statistically satisfactory (Tables 3 and 4), explaining $80.8 \%$ (prediction) to $99.8 \%$ (projection) of the total observed variation. In addition, they showed small values in sum of squares of error (SSE), root mean square error $(R M S E)$, absolute mean bias $(\bar{E})$ and standard errors. The parameters were also significant $(p<0.0001)$, according to the Student $t$ test, in all cases. The test was proposed for $\mathrm{H}_{0}: \beta_{\mathrm{i}}=0$. The probability $p<0.01$ indicates the value of the significance. The critical value we used was $\alpha=0.05$, so that any value of $p$ below this limit represented a rejection of $\mathrm{H}_{0}$ (if $p \leq \alpha$ ).

Table 3. Goodness-of-fit statistics of prediction and projection models.

\begin{tabular}{ccllll}
\hline Equation & SSE & $\boldsymbol{R M S E}$ & $\boldsymbol{R}^{\mathbf{2}}$-adj & $\overline{\boldsymbol{E}}$ & $\boldsymbol{A I C}$ \\
\hline \multicolumn{5}{c}{ Prediction } \\
\hline $5\left(D B H_{1}\right)$ & 316.4 & 2.232 & 0.886 & 0.097 & 111.45 \\
$7\left(D B H_{1}\right)$ & 337.5 & 2.306 & 0.879 & 0.020 & 115.71 \\
$9\left(B A_{1}\right)$ & 2102.2 & 5.754 & 0.831 & 0.344 & 236.43 \\
\hline
\end{tabular}


Table 3. Cont

\begin{tabular}{cccccc}
\hline Equation & $S S E$ & $R M S E$ & $R^{2}-a d j$ & $\bar{E}$ & $A I C$ \\
\hline $11\left(B A_{1}\right)$ & 2393.2 & 6.139 & 0.808 & 0.350 & 244.99 \\
$13\left(V_{1}\right)$ & $121,918.0$ & 43.646 & 0.925 & 6.825 & 502.42 \\
$15\left(V_{1}\right)$ & $24,648.7$ & 19.625 & 0.985 & 1.779 & 396.91 \\
\hline \multicolumn{7}{c}{ Projection } \\
\hline $6\left(D B H_{2}\right)$ & 9.2 & 0.378 & 0.997 & 0.028 & -121.83 \\
$8\left(D B H_{2}\right)$ & 8.6 & 0.364 & 0.997 & 0.045 & -126.81 \\
$10\left(B A_{2}\right)$ & 117.8 & 1.351 & 0.990 & 0.041 & 46.24 \\
$12\left(B A_{2}\right)$ & 70.7 & 1.047 & 0.994 & 0.207 & 12.58 \\
$14\left(V_{2}\right)$ & $20,373.3$ & 17.704 & 0.989 & 9.462 & 384.33 \\
$16\left(V_{2}\right)$ & $15,255.0$ & 15.320 & 0.992 & 4.145 & 365.24 \\
$17\left(L T_{2}\right)$ & $103,635.0$ & 39.930 & 0.998 & 3.901 & 487.69 \\
$18\left(L T_{2}\right)$ & $104,208.0$ & 40.040 & 0.998 & 3.839 & 488.06 \\
\hline
\end{tabular}

Where $S S E=$ sum of squares of error, $R M S E=$ root of mean square error, $R^{2}$-adj = coefficient of determination adjusted by the number of parameters, $\bar{E}=$ absolute mean bias, and $A I C=$ Akaike information criterion.

Table 4. Estimated parameters of prediction and projection models.

\begin{tabular}{|c|c|c|c|c|c|c|c|c|c|}
\hline Equations & Parameter & Estimate & $\begin{array}{l}\text { Standard } \\
\text { Error }\end{array}$ & $\operatorname{Pr}>|\mathrm{t}|$ & Equations & Parameter & Estimate & $\begin{array}{l}\text { Standard } \\
\text { Error }\end{array}$ & $\operatorname{Pr}>|\mathrm{t}|$ \\
\hline \multirow{4}{*}{ (5) and (6) } & $\beta_{0}$ & 2.478 & 0.354 & $<0.0001$ & \multirow{4}{*}{ (7) and (8) } & $\beta_{0}$ & -2.568 & 0.557 & $<0.0001$ \\
\hline & $\beta_{1}$ & -2.729 & 0.730 & $<0.0004$ & & $\beta_{1}$ & 0.705 & 0.053 & $<0.0001$ \\
\hline & $\beta_{2}$ & -0.204 & 0.033 & $<0.0001$ & & $\beta_{2}$ & 0.184 & 0.025 & $<0.0001$ \\
\hline & $\beta_{3}$ & 0.656 & 0.067 & $<0.0001$ & & $\beta_{3}$ & 2.329 & 0.194 & $<0.0001$ \\
\hline \multirow{4}{*}{ (9) and (10) } & $\beta_{0}$ & -3.613 & 0.599 & $<0.0001$ & \multirow{4}{*}{ (11) and (12) } & $\beta_{0}$ & -10.712 & 0.641 & $<0.0001$ \\
\hline & $\beta_{1}$ & -6.392 & 1.468 & $<0.0001$ & & $\beta_{1}$ & 0.095 & 0.021 & $<0.0001$ \\
\hline & $\beta_{2}$ & 0.566 & 0.053 & $<0.0001$ & & $\beta_{2}$ & 0.596 & 0.060 & $<0.0001$ \\
\hline & $\beta_{3}$ & 1.149 & 0.120 & $<0.0001$ & & $\beta_{3}$ & 3.722 & 0.250 & $<0.0001$ \\
\hline \multirow{3}{*}{ (13) and (14) } & $\delta_{0}$ & 2.843 & 0.128 & $<0.0001$ & \multirow{3}{*}{ (15) and (16) } & $\delta_{0}$ & 0.778 & 0.043 & $<0.0001$ \\
\hline & $\delta_{1}$ & -1.725 & 0.120 & $<0.0001$ & & $\delta_{1}$ & -13.580 & 0.627 & $<0.0001$ \\
\hline & $\delta_{2}$ & 0.278 & 0.034 & $<0.0001$ & & $\delta_{2}$ & 1.072 & 0.032 & $<0.0001$ \\
\hline (17) & $\alpha_{1}$ & -0.012 & 0.003 & $<0.0001$ & (18) & $\alpha_{1}$ & -0.00039 & 0.000 & $<0.0001$ \\
\hline
\end{tabular}

Equation: compatible equation.

Using the parameters estimated, it was possible to plot the families of growth curves in mean diameter, basal area, volume and mortality (Figure 2), as well as the residual plots corresponding to the observed and predicted data with the adjusted equations (Figure 3).

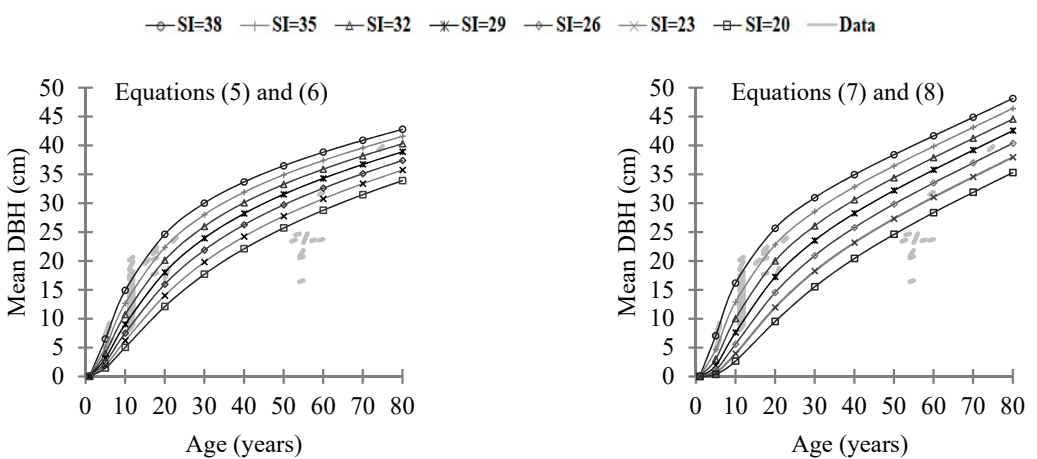

Figure 2. Cont. 

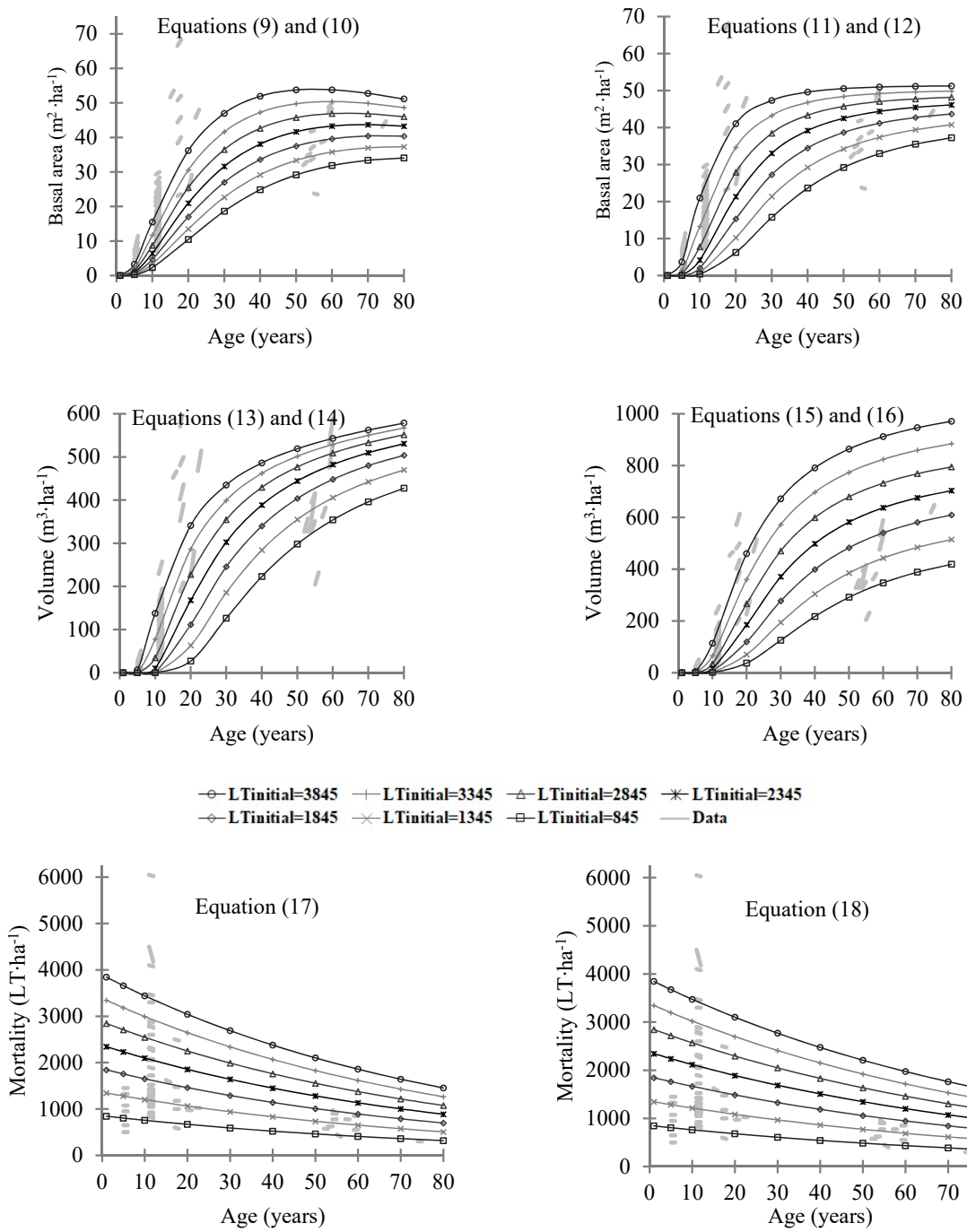

$$
=3345 \rightarrow \text { LTinitial }=2845 \rightarrow \text { LTinitial }=2345
$$$$
\text { Age (years) }
$$

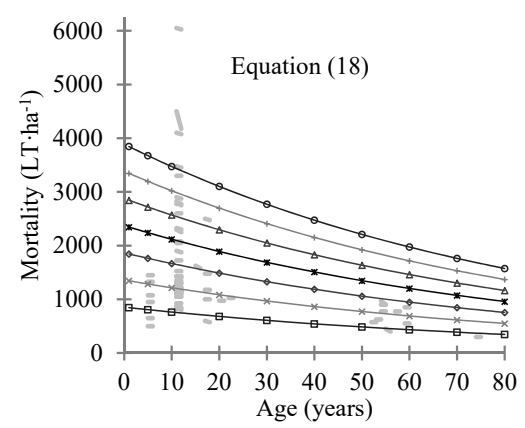

Figure 2. Families of growth curves for Pinus patula overlaid on the trajectories of the data observed in permanent sampling plots for the variables mean diameter at breast height, basal area and volume for different site qualities (SI = site index base age 40 years), and mortality with different initial densities $\left(L T_{1}\right)$. ( $D B H=$ diameter at breast height).
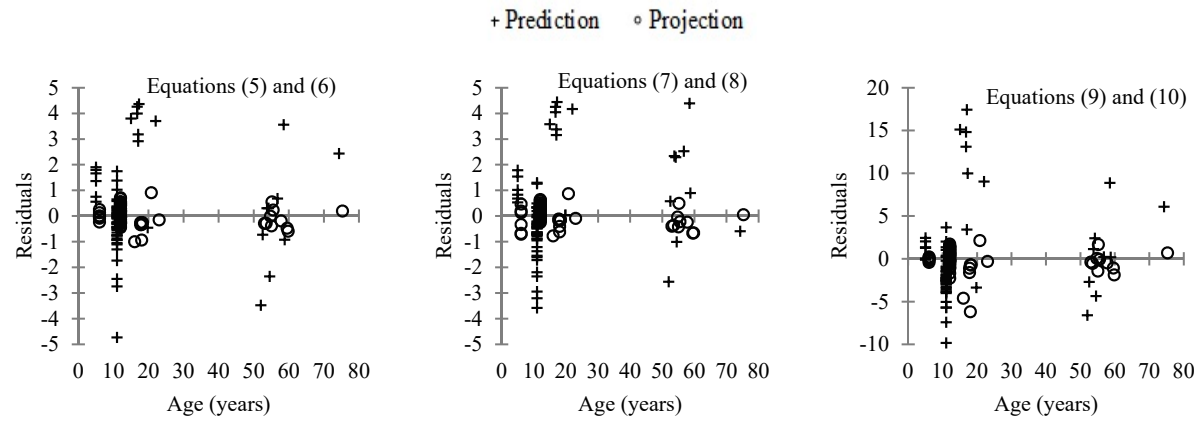

Figure 3. Cont. 

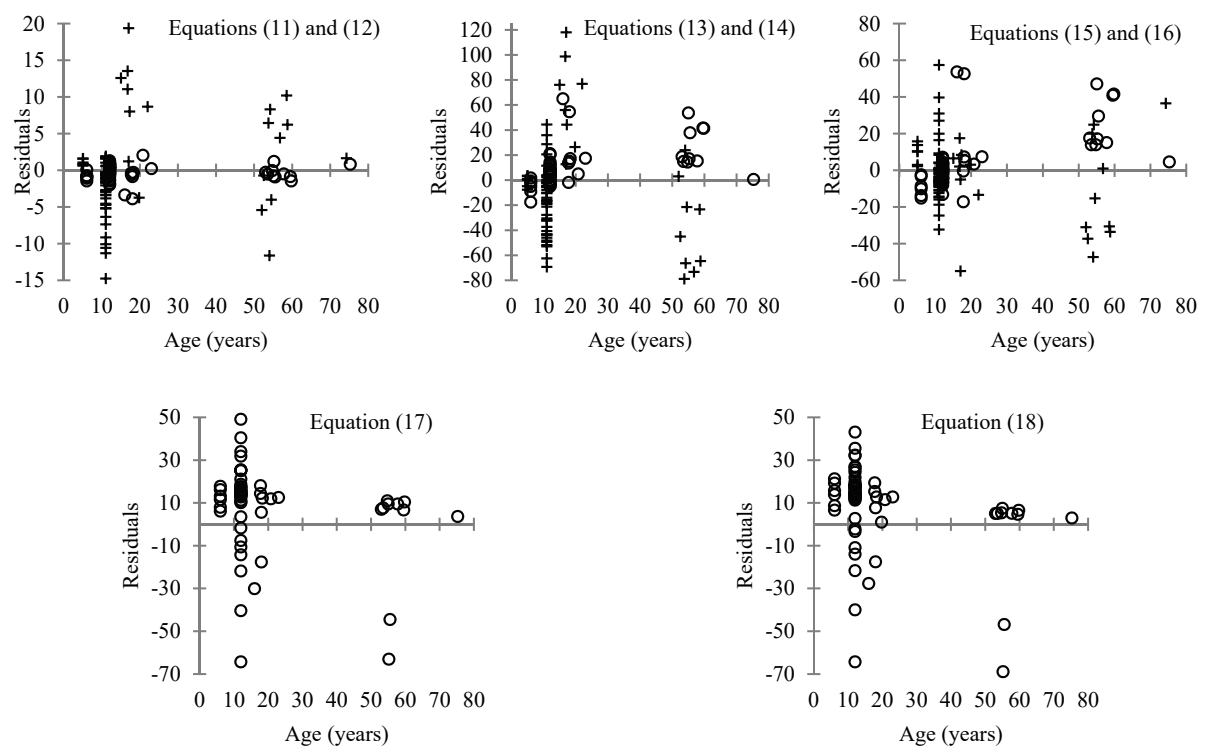

Figure 3. Residual plots of equations adjusted for state variables: average diameter at breast height (Equations (5)-(8)); basal area (Equations (9)-(12)); volume (Equations (13)-(16)), and; mortality (Equations (17) and (18)).

The compatible equations that best represent growth in average $D B H$ are 5-6 (indicated in the lower AIC), both in the plot (Figure 2) and statistically (Table 3). In addition, the residues (Figure 3) are similar than those that yielded Equations (7) and (8). These functions depend on age, site quality (dominant height) and number of trees (density).

The indicators of goodness of fit and residuals (Table 3 and Figure 3) indicate that Equations (11) and (12) adequately project growth in basal area because, while Equations (9) and (10) underestimate the basal area at early ages (Figure 2), Equations (11) and (12) have a more realistic behavior. In this way, the equations for modeling growth in basal area are in function of site quality (dominant height) and density (number of trees).

Compatible Equations (15) and (16) best describe volume growth because they are statistically superior (Table 3 and Figure 3) (Supplementary Materials Equations (13)-(16) in the supplementary information), presenting higher $R^{2} a d j$ and lower SSE and $\bar{E}$. In order to project mortality, Equation (17) was adequately adjusted (Table 3, Figures 2 and 3 ) to the observed data.

\subsection{Using the Compatible System}

The adjusted equations can represent, in numerical terms, the life of a stand using a yield table, which can determine the change in magnitude of each of the indicators of interest as age changes. It is important to mention that with the proposed SGTY, multiple yield tables can be constructed with many combinations for density management [16]. The yield table of variable density for $P$. patula stands with average SI $(29 \mathrm{~m})$ generates to an age of 18 years a maximum current annual increment of $26.43 \mathrm{~m}^{3} \mathrm{ha}^{-1}$ year $^{-1}$ (Table 5).

Table 5. Prediction of growth and timber yield for site index (SI) of $29 \mathrm{~m}$, considering an initial density of $1500 \mathrm{ha}^{-1}$ trees at 5 years.

\begin{tabular}{cccccccc}
\hline $\mathbf{A}$ & $\boldsymbol{L} \boldsymbol{T}$ & $\boldsymbol{D H}$ & $\boldsymbol{D B H}$ & $\boldsymbol{B A}$ & $\boldsymbol{V}$ & $\mathbf{C A I}$ & MAI \\
\hline 5 & 1500 & 2.41 & 2.76 & 0.27 & 0.23 & 0.05 & 0.05 \\
6 & 1482 & 3.40 & 3.80 & 0.75 & 1.05 & 0.82 & 0.17 \\
7 & 1463 & 4.47 & 4.86 & 1.59 & 3.24 & 2.19 & 0.46 \\
\hline
\end{tabular}


Table 5. Cont.

\begin{tabular}{cccccccc}
\hline $\mathbf{A}$ & $\boldsymbol{L T}$ & $\boldsymbol{D H}$ & $\boldsymbol{D B H}$ & $\boldsymbol{B A}$ & $\boldsymbol{V}$ & $\mathbf{C A I}$ & $\mathbf{M A I}$ \\
\hline 8 & 1446 & 5.57 & 5.91 & 2.82 & 7.64 & 4.40 & 0.96 \\
9 & 1428 & 6.69 & 6.94 & 4.43 & 14.97 & 7.33 & 1.66 \\
10 & 1410 & 7.81 & 7.93 & 6.36 & 25.63 & 10.66 & 2.56 \\
11 & 1393 & 8.91 & 8.89 & 8.53 & 39.70 & 14.07 & 3.61 \\
12 & 1376 & 10.00 & 9.81 & 10.85 & 56.97 & 17.27 & 4.75 \\
13 & 1359 & 11.06 & 10.70 & 13.26 & 77.04 & 20.06 & 5.93 \\
14 & 1343 & 12.09 & 11.54 & 15.69 & 99.39 & 22.35 & 7.10 \\
15 & 1326 & 13.08 & 12.34 & 18.08 & 123.49 & 24.10 & 8.23 \\
16 & 1310 & 14.05 & 13.11 & 20.42 & 148.82 & 25.33 & 9.30 \\
17 & 1294 & 14.98 & 13.85 & 22.66 & 174.91 & 26.09 & 10.29 \\
18 & 1278 & 15.87 & 14.55 & 24.79 & 201.34 & 26.43 & 11.19 \\
19 & 1262 & 16.73 & 15.22 & 26.80 & 227.78 & 26.43 & 11.99 \\
20 & 1247 & 17.56 & 15.87 & 28.69 & 253.93 & 26.16 & 12.70 \\
21 & 1232 & 18.36 & 16.49 & 30.45 & 279.60 & 25.66 & 13.31 \\
22 & 1217 & 19.13 & 17.08 & 32.10 & 304.60 & 25.01 & 13.85 \\
23 & 1202 & 19.86 & 17.65 & 33.62 & 328.83 & 24.23 & 14.30 \\
24 & 1187 & 20.57 & 18.19 & 35.03 & 352.19 & 23.36 & 14.67 \\
25 & 1172 & 21.26 & 18.72 & 36.33 & 374.64 & 22.44 & 14.99 \\
26 & 1158 & 21.92 & 19.22 & 37.54 & 396.13 & 21.50 & 15.24 \\
27 & 1144 & 22.55 & 19.71 & 38.64 & 416.67 & 20.54 & 15.43 \\
28 & 1130 & 23.16 & 20.18 & 39.67 & 436.25 & 19.58 & 15.58 \\
29 & 1116 & 23.75 & 20.64 & 40.61 & 454.89 & 18.64 & 15.69 \\
30 & 1102 & 24.31 & 21.08 & 41.47 & 472.61 & 17.72 & 15.75 \\
31 & 1089 & 24.86 & 21.50 & 42.27 & 489.44 & 16.83 & 15.79 \\
32 & 1076 & 25.38 & 21.92 & 43.00 & 505.42 & 15.97 & 15.79 \\
33 & 1062 & 25.89 & 22.32 & 43.68 & 520.57 & 15.15 & 15.77 \\
34 & 1049 & 26.38 & 22.71 & 44.30 & 534.93 & 14.36 & 15.73 \\
\hline
\end{tabular}

Where $A=$ stand age (years), $L T=$ number of live trees ha ${ }^{-1}, D H=$ dominant height $(\mathrm{m}), D B H=$ average stand of diameter at breast height $(\mathrm{cm}), B A=$ basal area $\left(\mathrm{m}^{2} \mathrm{ha}^{-1}\right), V=$ volume $\left(\mathrm{m}^{3} \mathrm{ha}^{-1}\right), \mathrm{CAI}=$ current annual increment $\left(\mathrm{m}^{3} \mathrm{ha}^{-1}\right.$ year $\left.^{-1}\right), \mathrm{MAI}=$ mean annual increment $\left(\mathrm{m}^{3} \mathrm{ha}^{-1}\right.$ year $\left.{ }^{-1}\right)$.

The yield tables allow calculation of the current annual increment (CAI) and the mean annual increment (MAI) by volume. In this way, it is possible to define the optimal age of rotation (CAI = MAI). For the case of the average SI $(29 \mathrm{~m})$, the optimal technical rotation in volume was at the age of 32 years (Table 5).

\section{Discussion}

The precision obtained in this study is similar to that reported by Romo et al. [15], who adjusted a system of equations to estimate tree growth in early stages, timber production, and storage of biomass and carbon in plantations of Pinus patula in Veracruz, Mexico, with a database in chrono-sequences and using the SUR technique. The precision obtained explained $74.0 \%$ to $99.8 \%$ of the total variability observed for dominant height, basal area, volume and biomass. Similar levels were obtained by Magaña et al. [14] when developing a system of equations to predict the growth and yield of Pinus rudis Endl. in Aloapan, Oaxaca, Mexico, based on data from permanent sampling plots.

According to Torres and Magaña [9] and Cancino [31], diameter increment is closely related to stand density, which is regulated by thinning. In general, the lower density the greater the tree growth. Therefore, models that predict diameter growth can provide information on the dynamics at a given age and initial condition. For this reason, it is possible to identify management strategies to optimize growth rates that meet the planned production objectives, to estimate harvest periods, and to plan activities for the protection and use of forest resources.

Modeling growth in basal area is important because basal area is directly related to the volume or mean square diameter. It is thus a tool for planning silvicultural interventions in stands or forests [23]. 
It also serves as a connection between the individual tree and stand models; that is, the estimates set a limit that should not be exceeded with individual tree models [32].

Compatible equations selected to model growth in volume use as independent variables age, site quality (SI) and basal area, which have been commonly used to model timber yield of $P$. rudis Endl. [14], Cedrela odorata L. and Tabebuia donnell-smithii Rose [13], P. patula [5,16] and Gmelina arborea [33].

By including the number of trees per hectare $(L T)$ as a prediction variable, the system acquires a "variable density" connotation, which is a property that is suitable for simulating different silvicultural regimes in different SIs [16]. The equation selected to model mortality is consistent with the model proposed by Clutter et al. [6] and Torres and Magaña [9], who mention that in many studies it has been proven that SI has little relation in the mortality functions. Santiago-García et al. [16] suggest that some minimum asymptotic value should be established when performing future yield forecasts because, by continuing to simulate mortality, the model will estimate zero trees per hectare, while in a forest under management this would happen only if a catastrophic event occurred.

Technical rotation estimated with the proposed growth system is less than the current technical rotation (40 years) in the forests of Ixtlán, Oaxaca, Mexico [17]. With the yield table, it is also possible to approximate the response the stand will have to thinning and to determine final cutting for different silvicultural regimes.

Another application of the SGTY is to provide inventory updates when there is no remeasurement in the permanent plots network, but it depends on the quality and time between remeasurements, since it is possible to estimate a new inventory from a previous one, or from an update of this type, and to estimate the sample size in case a new operational inventory is required [16].

The database used lacks data in the range of 25 to 50 years; thus, when making forecasts in this interval, certain reservations must be taken into account. It would be reliable if the projected variables maintain a realistic behavior.

\section{Conclusions}

It was possible to apply the curve development method with algebraic difference using forest inventory data from permanent sampling plots. The system of growth and explicit yield equations obtained is a reliable tool for dynamic modeling Pinus patula productive potential in accord with management, density and site quality. This tool is a contribution to the general knowledge of species around the world for decision-making processes, allowing long-term planning in sustainable forest management of plantations and even-aged stands. This research is a first approximation for this species in forests of Ixtlán, Oaxaca, México, with data of permanent sampling plots measured in a time interval. In order to improve the accuracy of the proposed models, extend the range of validity and establish new patterns of growth and natural mortality, it is suggested to increase the number of measurements and readjust the system, thereby improving the statistical indicators and the reliability of the proposed models.

Supplementary Materials: The following are available online at www.mdpi.com/1999-4907/8/12/465/s1, Data used and residuals for Equations (13)-(16).

Acknowledgments: We would like to acknowledge the Community of Ixtlán de Juárez and PRODEP for funding this work through project: 2-EA-1512 "Growth Models and Stand Density Management in Forests of Ixtlán de Juárez, Oaxaca, Mexico".

Author Contributions: W.S.-G. conceived the research design, conducted the field data collection, analysis, and wrote the manuscript. E.P.-L. was a co-principal author, assisted in the field data collection, analyzed the data and wrote the manuscript. G.Q.-B. and G.R.-O. assisted in analysis of the results and wrote the manuscript. E.S.-G. assisted in the field data collection and revised the manuscript. F.R.-A. and J.C.T.-U. revised the manuscript.

Conflicts of Interest: The authors declare no conflict of interest. 


\section{References}

1. Velázquez, A.; Ángeles, G.; Llanderal, T.; Román, A.; Reyes, V. Monografía de Pinus patula; Conafor-SemarnatColpos: Mexico City, Mexico, 2004.

2. Castellanos-Bolaños, J.F.; Treviño-Garza, E.J.; Aguirre-Calderón, Ó.A.; Jiménez-Pérez, J.; Musalem-Santiago, M.; López-Aguillón, R. Estructura de bosque de pino patula bajo manejo en Ixtlán de Juárez, Oaxaca, Mexico. Madera y Bosques 2008, 14, 51-63.

3. Madrigal, H.S.; Moreno, C.J.; Vázquez, C.I. Comparación de dos métodos de construcción de curvas de índice de sitio para Pinus pseudostrobus Lindl. Región Hidalgo-Zinapécuaro, Michoacán. Cienc. Nicolaita 2005, 40, 157-172.

4. Vanclay, J.K. Modelling Forest Growth and Yield, Applications to Mixed Tropical Forests; CAB International: Wallingford, UK, 1994.

5. Santiago-García, W.; De los Santos-Posadas, H.M.; Ángeles-Pérez, G.; Valdez-Lazalde, J.R.; Corral-Rivas, J.J.; Rodríguez-Ortiz, G.; Santiago-García, E. Modelos de crecimiento y rendimiento de totalidad del rodal para Pinus patula. Madera y Bosques 2015, 21, 95-110.

6. Clutter, J.L.; Forston, J.C.; Pienaar, L.V.; Brister, G.H.; Bailey, R.L. Timber Management: A Quantitative Approach; John Wiley \& Sons, Inc: New York, NY, USA, 1983.

7. Bailey, R.L.; Clutter, J.L. Base-age invariant polymorphic site curves. For. Sci. 1974, 20, 155-159.

8. Cieszewski, C.J.; Bailey, R.L. Generalized algebraic difference approach: Theory based derivation of dynamic site equations with polymorphism and variable asymptotes. For. Sci. 2000, 461, 116-126.

9. Torres, J.M.; Magaña, O.S. Evaluación de Plantaciones Forestales; Limusa: Mexico, Mexico, 2001.

10. De la Fuente, A.; Velázquez, A.; Torres, J.M.; Ramírez, H.; Rodríguez, C.; Trinidad, A. Predicción del crecimiento y rendimiento de Pinus rudis Endl., en Pueblos Mancomunados, Ixtlán, Oaxaca. Rev. Cien. For. Méx. 1998, 23, 3-8.

11. Montero, M.; Fierros, A.M. Predicción del crecimiento de Pinus caribaea var. hondurensis Barr y Golf. en "La Sabana", Oaxaca, Mexico. Rev. For. Centroam. 2000, 32, 20-25.

12. Zepeda, E.M.; Acosta, M. Incremento y rendimiento maderable de Pinus montezumae Lamb., en San Juan Tetla, Puebla. Madera y Bosques 2000, 6, 15-27. [CrossRef]

13. Galán, R.; De los Santos, H.M.; Valdez, J.I. Crecimiento y rendimiento maderable de Cedrela odorata L. y Tabebuia donnell-smithii Rose en San José Chacalapa, Pochutla, Oaxaca. Madera y Bosques 2008, 14, 65-82.

14. Magaña, O.S.; Torres, J.M.; Rodríguez, C.; Aguirre, H.; Fierros, A.M. Predicción de la producción y rendimiento de Pinus rudis Endl. en Aloapan, Oaxaca. Madera y Bosques 2008, 14, 5-19.

15. Romo, D.; Navarro, H.; De los Santos-Posadas, H.M.; Hernández, O.; López, J. Crecimiento maderable y biomasa aérea en plantaciones jóvenes de Pinus patula Schiede ex Schltdl. et Cham. en Zacualpan, Veracruz. Rev. Mex. Cien. For. 2014, 5, 78-91.

16. Santiago-García, W.; De los Santos-Posadas, H.M.; Ángeles-Pérez, G.; Valdez-Lazalde, J.R.; Ramírez-Valverde, G. Sistema compatible de crecimiento y rendimiento para rodales coetáneos de Pinus patula. Rev. Fitotec. Mex. 2013, $36,163-172$.

17. Servicios Técnicos Forestales de Ixtlán de Juárez. Programa de Manejo Forestal Para el Aprovechamiento y Conservación de Los Recursos Forestales Maderables de Ixtlán de Juárez. Ciclo de Corta 2015-2024; Servicios Técnicos Forestales de Ixtlán de Juárez: Oaxaca, Mexico, 2015; p. 111.

18. Assmann, E. The Principles of Forest Yield Study; Pergamon Press: Oxford, UK, 1970.

19. Alder, D. Estimación del Volumen Forestal y Predicción del Rendimiento Con Referencia Especial a Los Trópicos; Organización de las Naciones Unidas para la Agricultura y la Alimentación: Rome, Italy, 1980; p. 20. ISBN 92-5-300923-3.

20. Jacinto-Salinas, A.H. Modelos Alométricos Para Estimar Altura de Árboles en Bosques de Pino-Encino de Ixtlán, Oaxaca; Forestry Engineer, Instituto Tecnológico del Valle Oaxaca: Oaxaca, Mexico, 2016.

21. Rodríguez-Justino, R. Sistemas Compatibles de Cubicación de Árboles Individuales Para dos Especies de Interés Comercial en Ixtlán de Juárez, Oaxaca. Master's Thesis, Universidad de la Sierra Juárez, Oaxaca, Mexico, 2017.

22. Pérez-López, E. Sistema de Crecimiento y Rendimiento Maderable Para Rodales Coetáneos de Pinus patula Schiede ex Schlechtendal \& Chamisso; Forestry Engineer, Universidad de la Sierra Juárez: Oaxaca, Mexico, 2017. 
23. Diéguez-Aranda, U.; Castedo, F.; Álvarez, J.G. Funciones de crecimiento en área basimétrica para masas de Pinus sylvestris L. procedentes de repoblaciones en Galicia. Invest. Agr. Sist. Recur. For. 2005, 14, 253-266.

24. Pienaar, L.V.; Page, H.; Rheney, J.W. Yield prediction for mechanically site-prepared slash pine plantations. South. J. Appl. For. 1990, 14, 104-109.

25. Hui, G.; Gadow, K. Zur Modellierung der Bestandesgrundflächementwicklung dargestellt am Beispiel der Baumart Cunninghamia lanceolata. Allgemeine Forst- und Jagdzeitung 1993, 164, 144-145.

26. Santiago-García, W. Modelos de Crecimiento y Rendimiento Maderable Para Pinus oaxacana Mirov, de Ixtlán de Juárez, Oaxaca; Forestry Engineer, Instituto Tecnológico del Valle de Oaxaca: Oaxaca, Mexico, 2006.

27. Zhao, D.; Borders, B.; Wang, M.; Kane, M. Modeling mortality of second-rotation loblolly pine plantations in the Piedmont/Upper Coastal Plain and Lower Coastal Plain of the southern United States. For. Ecol. Manage 2007, 252, 132-143. [CrossRef]

28. SAS Institute Inc. SAS/ETS®9.3 User's Guide; SAS Institute Inc.: Cary, NC, USA, 2011.

29. Borders, B.E.; Souter, R.A.; Bailey, R.L.; Ware, K.D. Percentile-based distributions characterize forest stand tables. For. Sci. 1987, 33, 570-576.

30. Borders, B.E.; Patterson, W.D. Projecting stand tables: A comparison of the Weibull diameter distribution method, a percentile-based projection method, and a basal area growth projection method. For. Sci. 1990, 36, 413-424.

31. Cancino, J. Dendrometría Básica; Universidad de Concepción: Concepción, Chile, 2006; p. 124.

32. Gadow, K.V.; Real, P.; Álvarez, J.G. Modelización del Crecimiento y la Evolución de Los Bosques; IUFRO World Series: Viena, Austria, 2001.

33. Martínez-Zurimendi, P.; Domínguez-Domínguez, M.; Juárez-García, A.; López-López, L.M.; De la Cruz-Arias, V.; Álvarez-Martínez, J. Índice de sitio y producción maderable en plantaciones forestales de Gmelina arborea en Tabasco, Mexico (Ensayo). Rev. Fitotec. Mex. 2015, 38, 415-425.

(C) 2017 by the authors. Licensee MDPI, Basel, Switzerland. This article is an open access article distributed under the terms and conditions of the Creative Commons Attribution (CC BY) license (http:/ / creativecommons.org/licenses/by/4.0/). 